Review Article

\title{
The Role of Hematological Indices in Patients with Acute Coronary Syndrome
}

\author{
Jan Budzianowski, ${ }^{1}$ Konrad Pieszko, ${ }^{1}$ Paweł Burchardt, ${ }^{2,3}$ Janusz Rzeźniczak, ${ }^{3}$ and \\ Jarosław Hiczkiewicz ${ }^{1}$ \\ ${ }^{1}$ Department of Cardiology, Hospital Nowa Sól, Nowa Sól, Poland \\ ${ }^{2}$ Department of Biology and Environmental Sciences, Poznań University of Medical Sciences, Poznań, Poland \\ ${ }^{3}$ Department of Cardiology, J. Struś Hospital, Poznań, Poland
}

Correspondence should be addressed to Jan Budzianowski; jan.budzianowski@gmail.com

Received 13 June 2017; Accepted 21 August 2017; Published 3 October 2017

Academic Editor: Agata M. Bielecka-Dabrowa

Copyright (c) 2017 Jan Budzianowski et al. This is an open access article distributed under the Creative Commons Attribution License, which permits unrestricted use, distribution, and reproduction in any medium, provided the original work is properly cited.

\begin{abstract}
An increased systemic and local inflammation plays a key role in the pathophysiology of acute coronary syndrome (ACS). This review will discuss the role of hematological indices: white blood cells (WBC), neutrophil to lymphocyte ratio (NLR), red cell distribution width (RDW), and platelet indices, that is, platelet to lymphocyte ratio (PLR), mean platelet volume (MPV), and platelet distribution width (PDW) in the case of ACS. In recent years, a strong interest has been drawn to these indices, given that they may provide independent information on pathophysiology, risk stratification, and optimal management. Their lowcost and consequent wide and easy availability in daily clinical practice have made them very popular in the laboratory testing. Furthermore, many studies have pointed at their effective prognostic value in all-cause mortality, major cardiovascular events, stent thrombosis, arrhythmias, and myocardial perfusion disorders in terms of acute myocardial infarction and unstable angina. The most recent research also emphasizes their significant value in the combined analysis with other markers, such as troponin, or with GRACE, SYNTAX, and TIMI scores, which improve risk stratification and diagnosis in ACS patients.
\end{abstract}

\section{Introduction}

Coronary heart disease (CHD), most commonly caused by atherosclerosis, is the leading cause of death worldwide. Atherosclerosis is a systemic, lipid-driven immune inflammatory disease [1]. Inflammation, one of the factors leading to coronary artery disease (CAD), can be not only local but also systemic. Research carried out by Dutta et al. [2] proved that myocardial infarction is linked to an increased myeloid activity. Interestingly, it has also been shown that in the case of mice with an induced myocardial infarction, the sympathetic nervous system (SNS) becomes activated. This, in turn, induces the release of hematopoietic stem cells (HSPCs) from bone marrow niches, which consequently causes the further systemic stimulation of atherosclerotic plaques.

The chronic low-grade inflammation plays a key role in the initiation and development of the atherosclerotic plaque, which subsequently leads to the plaque's instability with a thrombus formation. Inflammation is also considered to be one of the main causes of diabetes, hyperlipidemia, metabolic syndrome, and endothelial dysfunction [3]. The inflammation leading to ACS encourages research into the clinical usage of new inflammatory biomarkers.

In this review, we shall describe the main hematological indices and their prognostic and diagnostic value in patients with ACS. In recent years, strong interest has arisen in these indices, given that they may provide independent information on pathophysiology, risk stratification, and optimal management.

The main advantage of hematological indices is that they are relatively inexpensive and thus widely and easily available in daily clinical practice. They have also proven their diagnostic and prognostic value in many cardiovascular diseases including CAD, atrial fibrillation following 
the coronary artery bypass graft (CABG) procedure, acute and chronic cardiac insufficiency, cardiac arrhythmias, and pulmonary hypertension.

\section{White Blood Cell Count (WBC)}

Leukocytes play a key role in the pathophysiology of ACS, given their effect on the instability of atherosclerotic plaques. In the initial stage, leukocytes permeate endothelial cells and become activated when reaching the tunica intima. They induce the formation of microvascularity there and, as a result, make plaques more susceptible to rupture [4]. Many studies have indicated that leukocytosis is related to an increased cardiovascular mortality rate. What is more, leukocytosis also proved to be of prognostic value when assessing adverse clinical outcomes [5-7].

In the study of Sabatine et al., the elevated WBC count was found to be a relevant death risk factor during the first 30 days and 6 months following the myocardial infarction among patients with ACS (UA, NSTEMI). Furthermore, the elevated level of WBC was also related to a more advanced CAD as well as epicardial and myocardial perfusion disorders [8]. In another study, the $\mathrm{WBC}>10,000$ pointed to increased mortality among AMI and UA patients. [9]

Many prospective studies have shown that the increased concentration of leukocytes on admission was connected not only to the development of worse microvascular injury, congestive heart failure, and shock but also to the elevated mortality rate in patients with ACS [10].

\section{Neutrophil to Lymphocyte Ratio (NLR)}

NLR is easily measured by dividing neutrophil count by lymphocyte count in a differential white blood cells (WBC) sample. It is one of the best-assessed hematological biomarkers, which provides prognostic and diagnostic information in ACS. Its role in cardiovascular diseases has been studied extensively in the past few years $[11,12]$.

The study of Sezer et al. proved that the increased number of neutrophils and MPV in patients with a front wall myocardial infarction is strongly and independently connected to the development of microvascular reperfusion injury after recanalisation of infarct-related artery [13]. In another study, activated neutrophils called polymorphonuclear cells (PMN) were found in coronary thrombi in patients with myocardial infarction who were undergoing primary percutaneous coronary intervention (PCI). PMN release neutrophil extracellular traps (NETs) at the culprit lesion site. NETs are highly proinflammatory and prothrombotic fibers which can entrap leucocytes and propagate thrombosis. NETs proved to be correlated negatively with STsegment resolution (STR) and positively with infarct size [14]. By contrast, lymphocytes, especially B2 and T helper, as the elements of the adaptive immune system, could mute and limit inflammation. The lower lymphocyte counts were associated with atherosclerosis progression and adverse clinical outcomes in patients with heart failure and ACS [15-17].

The combination of neutrophil and lymphocyte parameters has a better prognostic value than each parameter separately [18]. Kalay et al. demonstrated that NLR is related to the progression of coronary atherosclerosis, the process which is a strong and independent predictor of future coronary events [19]. In Wang et al. meta-analysis, NLR was a predictor of all-cause mortality and cardiovascular events in patients undergoing angiography or cardiac revascularization [20].

In the study of Tamhane et al., the admission NLR was described as a predictor of in-hospital and 6-month mortality in patients who undergo PCI. In the same study, it was proved that higher NLR was associated with diabetes and heart failure [21].

In recent years, numerous papers have been published regarding the value of NLR in predicting short- and longterm mortality in patients with ST-segment elevation (STEMI) [22-25] and with non-NSTEMI [26]. Preprocedural elevated NLR was also linked to an increased risk of significant ventricular arrhythmias during PCI [27].

NRL enables a clinician to predict stent thrombosis and the high mortality rate among patients with STEMI. NLR $>4.9$ had $70 \%$ accuracy and $65 \%$ specificity in predicting in-hospital mortality. In a multidimensional analysis, NLR was strongly linked to stent thrombosis [28].

Furthermore, NRL itself is referred to the complexity and severity of ACS assessed by SYNTAX score, GRACE scale, and TIMI score [29-31].

\section{Red Cell Distribution Width (RDW)}

RDW which is a part of a standard complete blood count (CBC) is a measure of variations in the volume of red blood cells. An elevation in RDW is known as anisocytosis. An increased level of RDW has been found in patients with vitamin B12, iron, and folate deficiency. RDW has also been observed after blood transfusion and hemolysis [32].

In the study of Patel et al., the RDW values above $14.0 \%$ were significantly related to a decreased red blood cell deformability, which can impair the blood flow through microcirculation. The resultant diminution of oxygen supply at the tissue level may help to explain the increased risk of adverse cardiovascular events associated with elevated RDW [33]. In 2007, Felker was one of the first authors who proved that the elevated RDW is a useful biomarker of morbidity and mortality among patients with heart failure [34]. In the study of Arbel et al., the RDW level of $12 \%$ and above is associated with an increased risk of cardiovascular morbidity and all-cause mortality in both anemic and nonanemic patients [35].

Many studies have highlighted that the increased RDW has also been linked to peripheral artery disease (PAD) [36], chronic obstructive pulmonary disease (COPD) [37], renal failure [38], sepsis and shock sepsis [39], cerebral atherosclerosis [40], stroke [41], and pulmonary hypertension [42]. Tonelli et al. indicated a relationship between higher levels of RDW and the risk of death and adverse cardiovascular outcomes in people with prior myocardial infarction but without symptomatic heart failure [43]. Moreover, it was shown that the elevated RDW was connected to a higher 
mortality rate in patients with a myocardial infarction (with or without anemia) [44-47].

In their study, Lippi et al. showed that the combined measure of RDW and troponin $\mathrm{T}$ (cTnT) increased diagnostic sensitivity to $99 \%$, which meant that the combined measure was more effective in diagnosing ACS than the measure of cTnT alone [48]. Moreover, it was proved that RDW is an essential predictor of CAD severity among patients with acute myocardial infarction (AMI) [49].

\section{Platelet Indices: PLR, PDW, and MPV}

Regardless of their role in the general (systemic) inflammatory response, platelets have been closely related to the activation and coordination of endothelium. It has recently been observed that there is a close relation between cardiovascular mortality and the number of platelets or their ability to aggregate. Platelets play a key role in the pathophysiology of ACS. Compounded with fibrin, platelets form coronary thrombus [1]. The CADILLAC study has shown that the level of platelets (which does not affect the effectiveness of percutaneous interventions) is significantly correlated with the incidence of restenosis and stent thrombosis [50], given the function of platelets in the local as well as general inflammatory response and their aspirin resistance [51, 52].

Platelets participate in the creation of blood clots and deliver mediators which develop and sustain a local inflammatory response [53]. MPV and PDW are important and simple markers which significantly increase during platelet activation [54]. Furthermore, these indices are helpful in the evaluation of thromboembolic diseases.

\section{Platelet to Lymphocyte Ratio (PLR)}

It turns out that the platelet to lymphocyte ratio is a useful parameter describing the systemic inflammatory response. Thus, it has become an important prognostic factor in numerous diseases. It has been shown that PLR correlates with the prognosis in esophageal, ovarian, rectal, and hepatocellular carcinoma as well as glioma multiform [55].

The roles of PLR and other complex markers of systemic inflammatory response have been primarily described in relation to the prognosis of ACS. It has been shown that PLR correlates with a greater overall mortality in patients with NSTEMI [56]. In the recently published (prospective) study involving 5886 patients, the same relation for STEMI has been presented [57]. The same study also showed that high PLR correlates with the recurrence of myocardial infarction, stroke, and subsequent heart failure. It seems that PLR is also helpful in predicting long-term results of percutaneous interventions and it can help select patients with a higher risk of no-reflow syndrome after pPCI $[58,59]$.

\section{Platelet Distribution Width (PDW)}

Platelet distribution width (PDW) indicates a varied size of platelets. The number of large immature platelets in patients with ACS is caused by an increased bone marrow activity during the process known as thrombocytopoiesis.
PDW measured on admission is a cheap and generally available biomarker which allows for predicting the development of heart failure in patients with ACS after PCI [60]. Bekler et al. showed that an increased level of PDW (>17\%) was related to the severity of CAD in patients with ACS. In the same study, an elevated PDW, diabetes mellitus, and myocardial infarction (MI) were positively correlated with a high Gensini score [61]. In a different study, PDW was greater in patients with STEMI than in those with stable CAD [62]. PDW also serves as a useful prognostic factor for long-term mortality in patients after AMI $[63,64]$.

\section{Mean Platelet Volume (MPV)}

MPV is a useful, indirect, and easily marked biomarker of platelet activity. Numerous studies support the association of MPV with adverse cardiac outcomes in patients with ACS.

MPV was a strong and independent predictor of impaired reperfusion and 6-month mortality in STEMI patients who underwent PCI $[65,66]$. A similar correlation was found in NSTEMI patients $[67,68]$. Moreover, Chu et al. showed that in patients who underwent PCI, the elevated MPV occurred in patients who developed restenosis [69]. Similarly, Huczek et al. proved that MPV was significantly higher in patients with ACS who developed an early stent thrombosis. It correlated with a poor dual antiplatelet responsiveness [70]. In another study of 462 patients with CAD who underwent PCI, higher MPV levels were independently associated with high residual platelet reactivity after both aspirin and clopidogrel treatments [71]. This is due to the fact that larger platelets are more often reticulated than smaller platelets containing more prothrombotic material (thromboxane A2, platelet factor 4, alpha-granules, $\mathrm{P}$-selectin, and platelet-derived growth factor), which is an independent predictor of a poor response to dual antiplatelet therapy [72].

MPV turned to be independently responsible for the slow coronary flow (SCF) occurrence and its extent [73]. In the recent years, the correlation of $\mathrm{WBC}$ to $\mathrm{MPV}$ has been named as the $\mathrm{WBC} / \mathrm{MPV}$ ratio (WMR). The relationship between WMR and major adverse cardiovascular events (MACE) in patients with NSTEMI [74] and STEMI [75] was more prominent than with WBC and MPV, respectively.

\section{Conclusions}

There is a high demand for a reliable, accessible, noninvasive, and hematological prognostic marker in ACS, which would identify patients of high cardiovascular risk in secondary prevention and tailor the therapy to their needs. Many of the indices presented here reflect the complex pathophysiology of ACS. The inflammatory processes play a key role in the development of atherosclerosis, destabilisation of atherosclerotic plaques and formation of clots on the plaque surface [76]. The significance of NLR, PLR, PDW, MPV, and RDW in the prognosis of ACS has been indicated in many studies as it has been shown above. The most crucial studies concerning hematological indices have been summarized in Table 1. 
TABLE 1: Summary of some studies investigating diagnostic and prognostic role of the most important hematological indices.

\begin{tabular}{|c|c|c|c|c|}
\hline Study type & Study & Sample size & Main findings & References \\
\hline \multicolumn{5}{|l|}{$W B C$} \\
\hline Retrospective & Cannon et al. (2001) & 7651 patients with ACS & $\begin{array}{l}\text { WBC count of }>10,000 \text { was associated with } \\
\text { increased } 30 \text {-day and } 10 \text {-month mortality. }\end{array}$ & [9] \\
\hline Retrospective & Barron et al. (2000) & 975 patients with MI & $\begin{array}{l}\text { Elevation in WBC count was associated with } \\
\text { reduced epicardial blood flow and myocardial } \\
\text { perfusion, thromboresistance, and a higher } \\
\text { incidence of new congestive heart failure } \\
\text { and death. }\end{array}$ & {$[10]$} \\
\hline Prospective & Sabatine et al. (2002) & $\begin{array}{l}2220 \text { patients with } \\
\text { UA/NSTEMI }\end{array}$ & $\begin{array}{l}\text { Higher baseline WBC count was associated } \\
\text { with impaired epicardial and myocardial } \\
\text { perfusion, more extensive CAD, and higher } \\
\text { six-month mortality rates. }\end{array}$ & [8] \\
\hline Retrospective & Gurm et al. (2003) & 4450 patients & $\begin{array}{l}\text { A low or an elevated preprocedural WBC count } \\
\text { in patients undergoing PCI is associated with } \\
\text { an increased risk of long-term death. }\end{array}$ & {$[11]$} \\
\hline Prospective & Chia et al. (2009) & 363 patients with STEMI & $\begin{array}{l}\text { Elevated leucocyte and neutrophils are } \\
\text { predictors of adverse cardiac events. }\end{array}$ & {$[12]$} \\
\hline \multicolumn{5}{|l|}{$N L R$} \\
\hline Prospective & Duffy et al. (2006) & $\begin{array}{l}1046 \text { patients who } \\
\text { underwent PCI }\end{array}$ & $\begin{array}{l}\text { The NLR was an independent significant } \\
\text { predictor of long-term mortality in patients } \\
\text { who have undergone coronary angiography. }\end{array}$ & {$[18]$} \\
\hline Prospective & Tamhane et al. (2008) & 2833 patients with ACS & $\begin{array}{l}\text { NLR was a predictor of in-hospital and 6-month } \\
\text { mortality in patients who undergo PCI. }\end{array}$ & {$[21]$} \\
\hline Prospective & Núñez et al. (2008) & 515 patients with STEMI & $\begin{array}{l}\text { NLR was a useful marker to predict subsequent } \\
\text { mortality in patients admitted for STEMI, with } \\
\text { a superior discriminative ability than total WBC. }\end{array}$ & {$[22]$} \\
\hline Prospective & Azab et al. (2010) & 1345 patients with NSTEMI & $\begin{array}{l}\text { NLR is an independent predictor of } \\
\text { short-term and long-term mortalities in } \\
\text { patients with NSTEMI. }\end{array}$ & {$[26]$} \\
\hline Retrospective & $\begin{array}{l}\text { Chatterjee et al. } \\
\qquad(2011)\end{array}$ & $\begin{array}{l}\text { 30,798 records who have } \\
\text { undergone coronary } \\
\text { angiography }\end{array}$ & $\begin{array}{c}\text { A preprocedural NLR, elevated WBC count, and } \\
\text { neutrophils were predictors of significant } \\
\text { ventricular arrhythmias in patients } \\
\text { undergoing PCI. }\end{array}$ & {$[27]$} \\
\hline Prospective & Akpek et al. (2012) & $\begin{array}{l}418 \text { patients with STEMI } \\
\text { who underwent PCI }\end{array}$ & $\begin{array}{l}\text { The NLR was independently associated with } \\
\text { the development of no-reflow and in-hospital } \\
\text { MACEs in patients with ST-segment elevation } \\
\text { myocardial infarction undergoing primary PCI. }\end{array}$ & {$[23]$} \\
\hline Prospective & Sahin et al. (2013) & $\begin{array}{l}840 \text { patients with STEMI } \\
\text { who underwent PCI }\end{array}$ & $\begin{array}{l}\text { NLR was the independent predictor for } \\
\text { SYNTAX } \\
\text { score in patients with STEMI. }\end{array}$ & {$[24]$} \\
\hline Retrospective & Sawant et al. (2014) & $\begin{array}{l}250 \text { consecutive } \\
\text { STEMI patients }\end{array}$ & $\begin{array}{l}\text { NLR based on an optimal cut-off value of } \\
7.4 \text { was an excellent predictor of short- and } \\
\text { long-term survival in patients with } \\
\text { revascularized STEMI. }\end{array}$ & {$[31]$} \\
\hline Retrospective & Ayça et al. (2015) & $\begin{array}{l}102 \text { patients with stent } \\
\text { tshrombosis and } 450 \\
\text { patients with STEMI }\end{array}$ & $\begin{array}{l}\text { In patients with STEMI, preprocedural high } \\
\text { NLR was associated with both stent } \\
\text { thrombosis and higher mortality rates. }\end{array}$ & [28] \\
\hline Prospective & Yaylak et al. (2016) & $\begin{array}{l}\text { A total of } 213 \text { subjects } \\
\text { with inferior STEMI }\end{array}$ & $\begin{array}{c}\text { NLR was an independent predictor of RVD } \\
\text { in patients with inferior STEMI undergoing } \\
\text { primary PCI. }\end{array}$ & {$[25]$} \\
\hline \multicolumn{5}{|l|}{$R D W$} \\
\hline Retrospective & Nabais et al. (2009) & 1796 patients with ACS & $\begin{array}{c}\text { There is a graded independent association } \\
\text { between higher RDW values and adverse } \\
\text { outcomes in patients with ACS. }\end{array}$ & {$[45]$} \\
\hline
\end{tabular}


TABle 1: Continued.

\begin{tabular}{|c|c|c|c|c|}
\hline Study type & Study & Sample size & Main findings & References \\
\hline Prospective & Lippi et al. (2009) & 456 patients with ACS & $\begin{array}{l}\text { RDW at admission might be considered } \\
\text { with other conventional cardiac markers for } \\
\text { the risk stratification of ACS patients admitted } \\
\text { to emergency departments. }\end{array}$ & {$[48]$} \\
\hline Prospective & Dabbah et al. (2010) & 1709 patients with AMI & $\begin{array}{c}\text { RDW is a predictor of mortality after AMI. } \\
\text { Moreover, an increase in RDW during } \\
\text { hospitalization also portends adverse } \\
\text { clinical outcome. }\end{array}$ & {$[44]$} \\
\hline Retrospective & Uyarel et al. (2011) & 2506 STEMI patients & $\begin{array}{c}\text { RDW at admission was a predictor of } \\
\text { in-hospital and long-term cardiovascular } \\
\text { mortality. }\end{array}$ & {$[46]$} \\
\hline Prospective & Isik et al. (2012) & 135 patients with STEMI & $\begin{array}{c}\text { RDW is a marker indicating long-term } \\
\text { prognosis. }\end{array}$ & [47] \\
\hline Prospective & Timóteo et al. (2015) & 787 patients with ACS & $\begin{array}{c}\text { Combination of RDW with GRACE score } \\
\text { improves the predictive value for all-cause } \\
\text { mortality. }\end{array}$ & {$[80]$} \\
\hline \multicolumn{5}{|l|}{$P L R$} \\
\hline $\begin{array}{l}\text { Observational } \\
\text { study }\end{array}$ & Azab et al. (2012) & 619 patients with NSTEMI & $\begin{array}{l}\text { PLR is a significant independent predictor } \\
\text { of long-term mortality after NSTEMI. }\end{array}$ & {$[56]$} \\
\hline Prospective & Kurtul et al. (2014) & 1016 patients with ACS & $\begin{array}{l}\text { PLR at admission is significantly associated } \\
\text { with the severity and complexity of coronary } \\
\text { atherosclerosis in patients with ACS. } \\
\text { Increased PLR is an independent predictor } \\
\text { of higher SYNTAX score in patients with } \\
\text { ACS who undergo urgent CA. }\end{array}$ & {$[82]$} \\
\hline Retrospective & Acet et al. (2016) & 800 patients with STEMI & $\begin{array}{l}\text { PLR, RDW and monocyte were associated } \\
\text { with GRACE score in patients with STEMI. }\end{array}$ & {$[81]$} \\
\hline Retrospective & Yildiz et al. (2015) & 287 patients with STEMI & $\begin{array}{l}\text { High preprocedural PLR and NLR levels are } \\
\text { significant and independent predictors of } \\
\text { no-reflow in patients undergoing primary PCI. }\end{array}$ & {$[58]$} \\
\hline Prospective & Sun et al. (2017) & 5886 patients with STEMI & $\begin{array}{c}\text { Higher PLR was associated with recurrent } \\
\text { myocardial infarction, heart failure, ischemic } \\
\text { stroke, and all-cause mortality in patients } \\
\text { with STEMI. }\end{array}$ & {$[57]$} \\
\hline Prospective & Vakili et al. (2017) & 215 patients with STEMI & $\begin{array}{l}\text { PLR and NLR were associated with no-reflow } \\
\text { phenomenon in patients with STEMI treated } \\
\text { with pPCI. }\end{array}$ & [59] \\
\hline \multicolumn{5}{|l|}{$P D W$} \\
\hline Prospective & De Luca et al. (2010) & $\begin{array}{l}1882 \text { patients undergoing } \\
\text { coronary angiography + IMT } \\
\text { in } 359 \text { patients }\end{array}$ & $\begin{array}{c}\text { PDW is not related to the extent of CAD and } \\
\text { carotid IMT. PDW positively correlated } \\
\text { with age, weight, waist circumference, and } \\
\text { prevalence of diabetes. }\end{array}$ & {$[78]$} \\
\hline Prospective & $\begin{array}{l}\text { Rechciński et al. } \\
\qquad(2013)\end{array}$ & $\begin{array}{l}538 \text { patients who underwent } \\
\text { primary PCI in acute MI }\end{array}$ & $\begin{array}{c}\text { PDW and P-LCR are prognostic predictors } \\
\text { after MI. }\end{array}$ & {$[63]$} \\
\hline Retrospective & Celik et al. (2015) & 306 patients with STEMI & $\begin{array}{c}\text { Baseline PDW and MPV are independent } \\
\text { correlates of no-reflow and in-hospital } \\
\text { MACEs among patients with STEMI } \\
\text { undergoing pPCI. }\end{array}$ & {$[64]$} \\
\hline Retrospective & Bekler et al. (2015) & $\begin{array}{l}502 \text { patients with ACS } \\
\text { were enrolled. }\end{array}$ & $\begin{array}{c}\text { The group with PDW }>17 \% \text { had significantly } \\
\text { higher Gensini score. }\end{array}$ & {$[61]$} \\
\hline \multicolumn{5}{|l|}{$M P V$} \\
\hline Prospective & Huczek et al. (2005) & 398 patients with STEMI & $\begin{array}{l}\text { MPV is a predictor of impaired reperfusion } \\
\text { and mortality in STEMI treated with pPCI. }\end{array}$ & {$[65]$} \\
\hline
\end{tabular}


TABLe 1: Continued.

\begin{tabular}{|c|c|c|c|c|}
\hline Study type & Study & Sample size & Main findings & References \\
\hline Case-control study & Huczek et al. (2010) & $\begin{array}{l}36 \text { consecutive ST cases } \\
\text { and } 72 \text { matched controls }\end{array}$ & $\begin{array}{c}\text { Baseline platelet size is increased in patients } \\
\text { with ACS developing early stent thrombosis } \\
\text { and correlates with future residual platelet } \\
\text { reactivity. }\end{array}$ & {$[70]$} \\
\hline $\begin{array}{l}\text { Systematic } \\
\text { review + meta- } \\
\text { analisis }\end{array}$ & Chu et al. 2010 & $\begin{array}{l}\text { Pooled results from } 16 \\
\text { cross-sectional studies } \\
\text { involving } \\
2809 \text { patients with CAD }\end{array}$ & $\begin{array}{l}\text { Elevated MPV is associated with AMI, } \\
\text { mortality following myocardial infarction, and } \\
\text { restenosis following coronary angioplasty. }\end{array}$ & [69] \\
\hline Retrospective & Isik et al. (2012) & $\begin{array}{l}2467 \text { who underwent } \\
\text { coronarography with CAD }\end{array}$ & $\begin{array}{l}\text { Diabetes, smoking, hemoglobin, and MPV were } \\
\text { found to be the independent correlates of SCF } \\
\text { presence. Moreover, only MPV was identified } \\
\text { as an independent correlate of extent of SCF. }\end{array}$ & [73] \\
\hline Prospective & Wan et al. (2014) & 297 ACS patients & $\begin{array}{l}\text { Both MPV and the GRACE score were } \\
\text { significant and independent predictors for } \\
\text { CVD events. } \\
\text { Combination of MPV with the scoring system } \\
\text { improved the predictive value. }\end{array}$ & [83] \\
\hline Prospective & Niu et al. (2015) & 506 ACS patients & $\begin{array}{l}\text { Elevated MPV was an independent predictor } \\
\text { of 6-month mortality or MI in patients with } \\
\text { ACS. } \\
\text { The addition of MPV to the GRACE model } \\
\text { improved its predictive value. }\end{array}$ & {$[84]$} \\
\hline
\end{tabular}

ACS: acute coronary syndrome; AMI: acute myocardial infarction; NSTEMI: non-ST elevation myocardial infarction; MI: myocardial infarction; MPV: mean platelet volume; STEMI: ST elevation myocardial infarction; CAD: coronary artery disease; TIMI: thrombolysis in myocardial infarction; WBC: white blood cell count; RDW: red blood cell distribution width; PDW: platelet distribution width; PLR: platelet lymphocyte ratio; P-LCR: platelet large cell ratio; CVD: cardiovascular disease; HF: heart failure; PCI: percutaneous coronary intervention; RVD: right ventricular dysfunction; MACEs: major adverse cardiac events; GRACE: global registry of acute coronary events; SCF: slow coronary flow; IMT: intima media thickness.

Dutta et al. showed that ACS increases inflammation in the atherosclerotic plaques within months [2]. Therefore, the questions to be asked are at which stage of ACS would it be best to test biomarkers and would repeated tests improve their prognostic value? It is worth emphasizing that EDTA as an anticoagulant can cause platelet swelling thereby affecting the value of PDW and MPV [77]. Moreover, it is worth paying attention to the possible influence of medication on the value of hematological biomarkers; for example, statins had an effect on the higher value of PDW [78]. In a different study, statins considerably diminished MPV [79]. It is also important to mention that the value of hematological biomarkers in ACS patients is affected by other health disorders such as chronic renal failure, anemia, thrombocytopenia, thyroid dysfunction, dyslipidemia, diabetes, and hypertension. What is more, these disorders anticipate worse prognosis for patients with ACS, given their increased chance of heightened inflammation, oxidative stress, and apoptosis in bone marrow, which all negatively affect the function of erythropoiesis (inflammatory cytokines suppress the maturation of erythrocytes). Interestingly, biomarkers have an additional prognostic value for ACS patients if they are analysed with other inflammatory markers (such as CRP and fibrinogen) or with GRACE, SYNTAX, and TIMI risk scores [80-84].

\section{Conflicts of Interest}

The authors declare no conflict of interests.

\section{References}

[1] E. Falk, M. Nakano, J. F. Bentzon, A. V. Finn, and R. Virmani, "Update on acute coronary syndromes: the pathologists' view," European Heart Journal, vol. 34, no. 10, pp. 719-728, 2013.

[2] P. Dutta, G. Courties, Y. Wei et al., "Myocardial infarction accelerates atherosclerosis," Nature, vol. 487, no. 7407, pp. 325-329, 2012.

[3] S. Balta, E. Kurtoglu, U. Kucuk, S. Demirkol, and C. Ozturk, "Neutrophil-lymphocyte ratio as an important assessment tool," Expert Review of Cardiovascular Therapy, vol. 12, no. 5, pp. 537-538, 2014.

[4] M. Madjid, I. Awan, J. T. Willerson, and S. W. Casscells, "Leukocyte count and coronary heart disease: implications for risk assessment," Journal of the American College of Cardiology, vol. 44, no. 10, pp. 1945-1956, 2004.

[5] K. Ensrud and R. H. Grimm Jr., "The white blood cell count and risk for coronary heart disease," American Heart Journal, vol. 124, no. 1, pp. 207-213, 1992.

[6] J. W. Yarnell, I. A. Baker, P. M. Sweetnam et al., "Fibrinogen, viscosity, and white blood cell count are major risk factors for ischemic heart disease. The Caerphilly and Speedwell collaborative heart disease studies," Circulation, vol. 83, no. 3, pp. 836-844, 1991.

[7] A. J. Grau, A. W. Boddy, D. A. Dukovic et al., "Leukocyte count as an independent predictor of recurrent ischemic events," Stroke, vol. 35, no. 5, pp. 1147-1152, 2004.

[8] M. S. Sabatine, D. A. Morrow, C. P. Cannon et al., "Relationship between baseline white blood cell count and degree of coronary artery disease and mortality in patients with acute 
coronary syndromes," Journal of the American College of Cardiology, vol. 40, no. 10, pp. 1761-1768, 2002.

[9] C. P. Cannon, C. H. McCabe, R. G. Wilcox, J. H. Bentley, and E. Braunwald, "Association of white blood cell count with increased mortality in acute myocardial infarction and unstable angina pectoris," The American Journal of Cardiology, vol. 87, no. 5, pp. 636-639, 2001.

[10] H. V. Barron, C. P. Cannon, S. A. Murphy, E. Braunwald, and C. M. Gibson, "Association between white blood cell count, epicardial blood flow, myocardial perfusion, and clinical outcomes in the setting of acute myocardial infarction: a thrombolysis in myocardial infarction 10 substudy," Circulation, vol. 102, no. 19, pp. 2329-2334, 2000.

[11] H. S. Gurm, D. L. Bhatt, R. Gupta, S. G. Ellis, E. J. Topol, and M. S. Lauer, "Preprocedural white blood cell count and death after percutaneous coronary intervention," American Heart Journal, vol. 146, no. 4, pp. 692-698, 2003.

[12] S. Chia, J. T. Nagurney, D. F. Brown et al., "Association of leukocyte and neutrophil counts with infarct size, left ventricular function and outcomes after percutaneous coronary intervention for ST-elevation myocardial infarction," The American Journal of Cardiology, vol. 103, no. 3, pp. 333-337, 2009.

[13] M. Sezer, I. Okcular, T. Goren et al., "Association of haematological indices with the degree of microvascular injury in patients with acute anterior wall myocardial infarction treated with primary percutaneous coronary intervention," Heart, vol. 93, no. 3, pp. 313-318, 2007.

[14] A. Mangold, S. Alias, T. Scherz et al., "Coronary neutrophil extracellular trap burden and deoxyribonuclease activity in ST-elevation acute coronary syndrome are predictors of stsegment resolution and infarct size," Circulation Research, vol. 116, no. 7, pp. 1182-1192, 2015.

[15] A. S. Major, S. Fazio, and M. F. Linton, "B-lymphocyte deficiency increases atherosclerosis in LDL receptor-null mice," Arteriosclerosis, Thrombosis, and Vascular Biology, vol. 22, no. 11, pp. 1892-1898, 2002.

[16] M. Vaduganathan, A. P. Ambrosy, S. J. Greene et al., "Predictive value of low relative lymphocyte count in patients hospitalized for heart failure with reduced ejection fraction: insights from the EVEREST trial," Circulation: Heart Failure, vol. 5, no. 6, pp. 750-758, 2012.

[17] E. G. Zouridakis, X. Garcia-Moll, and J. C. Kaski, "Usefulness of the blood lymphocyte count in predicting recurrent instability and death in patients with unstable angina pectoris," The American Journal of Cardiology, vol. 86, no. 4, pp. 449-451, 2000.

[18] B. K. Duffy, H. S. Gurm, V. Rajagopal, R. Gupta, S. G. Ellis, and D. L. Bhatt, "Usefulness of an elevated neutrophil to lymphocyte ratio in predicting long-term mortality after percutaneous coronary intervention," The American Journal of Cardiology, vol. 97, no. 7, pp. 993-996, 2006.

[19] N. Kalay, O. Dogdu, F. Koc et al., "Hematologic parameters and angiographic progression of coronary atherosclerosis," Angiology, vol. 63, no. 3, pp. 213-217, 2012.

[20] X. Wang, G. Zhang, X. Jiang, H. Zhu, Z. Lu, and L. Xu, "Neutrophil to lymphocyte ratio in relation to risk of allcause mortality and cardiovascular events among patients undergoing angiography or cardiac revascularization: a metaanalysis of observational studies," Atherosclerosis, vol. 234, no. 1, pp. 206-213, 2014.

[21] U. U. Tamhane, S. Aneja, D. Montgomery, E.-K. Rogers, K. A. Eagle, and H. S. Gurm, "Association between admission neutrophil to lymphocyte ratio and outcomes in patients with acute coronary syndrome," The American Journal of Cardiology, vol. 102, no. 6, pp. 653-657, 2008.

[22] J. Núñez, E. Núñez, V. Bodí et al., "Usefulness of the neutrophil to lymphocyte ratio in predicting long-term mortality in ST segment elevation myocardial infarction," The American Journal of Cardiology, vol. 101, no. 6, pp. 747-752, 2008.

[23] M. Akpek, M. G. Kaya, Y. Y. Lam et al., "Relation of neutrophil/lymphocyte ratio to coronary flow to in-hospital major adverse cardiac events in patients with ST-elevated myocardial infarction undergoing primary coronary intervention," The American Journal of Cardiology, vol. 110, no. 5, pp. 621-627, 2012.

[24] D. Y. Sahin, Z. Elbasan, M. Gür et al., "Neutrophil to lymphocyte ratio is associated with the severity of coronary artery disease in patients with ST-segment elevation myocardial infarction," Angiology, vol. 64, no. 6, pp. 423-429, 2013.

[25] B. Yaylak, H. Ede, E. Baysal et al., "Neutrophil/lymphocyte ratio is associated with right ventricular dysfunction in patients with acute inferior ST-segment elevation myocardial infarction," Cardiology Journal, vol. 23, no. 1, pp. 100-106, 2016.

[26] B. Azab, M. Zaher, K. F. Weiserbs et al., "Usefulness of neutrophil to lymphocyte ratio in predicting short- and long-term mortality after non-ST-elevation myocardial infarction," The American Journal of Cardiology, vol. 106, no. 4, pp. 470-476, 2010.

[27] S. Chatterjee, P. Chandra, G. Guha et al., "Pre-procedural elevated white blood cell count and neutrophil-lymphocyte (N/L) ratio are predictors of ventricular arrhythmias during percutaneous coronary intervention," Cardiovascular \& Hematological Disorders-Drug Targets, vol. 11, no. 2, pp. 58-60, 2011.

[28] B. Ayça, F. Akın, O. Celik et al., "Neutrophil to lymphocyte ratio is related to stent thrombosis and high mortality in patients with acute myocardial infarction," Angiology, vol. 66, no. 6, pp. 545-552, 2015.

[29] B. Altun, H. Turkon, H. Tasolar et al., "The relationship between high-sensitive troponin $\mathrm{T}$, neutrophil lymphocyte ratio and SYNTAX score," Scandinavian Journal of Clinical Laboratory Investigation, vol. 74, no. 2, pp. 108-115, 2014.

[30] M. Ergelen, H. Uyarel, S. Altay et al., "Predictive value of elevated neutrophil to lymphocyte ratio in patients undergoing primary angioplasty for ST-segment elevation myocardial infarction," Clinical and Applied Thrombosis/Hemostasis, vol. 20, no. 4, pp. 427-432, 2014.

[31] A. C. Sawant, P. Adhikari, S. R. Narra, S. V. Srivatsa, P. K. Mills, and S. S. Srivatsa, "Neutrophil to lymphocyte ratio predicts short- and long-term mortality following revascularization therapy for ST elevation myocardial infarction," Cardiology Journal, vol. 21, no. 5, pp. 500-508, 2014.

[32] E. Sertoglu, S. Tapan, and M. Uyanik, "Important details about the red cell distribution width," Journal of Atherosclerosis and Thrombosis, vol. 22, no. 2, pp. 219-220, 2015.

[33] K. V. Patel, J. G. Mohanty, B. Kanapuru, C. Hesdorffer, W. B. Ershler, and J. M. Rifkind, "Association of the red cell distribution width with red blood cell deformability," in Oxygen Transport to Tissue XXXIV, pp. 211-216, Springer, New York, NY, USA, 2013.

[34] G. M. Felker, L. A. Allen, S. J. Pocock et al., "Red cell distribution width as a novel prognostic marker in heart failure: data from the CHARM Program and the Duke Databank," Journal of the American College of Cardiology, vol. 50, no. 1, pp. 40-47, 2007. 
[35] Y. Arbel, R. Raz, D. Weitzman et al., "Red blood cell distribution width and the risk of cardiovascular morbidity and allcause mortality: a population-based study," European Heart Journal, vol. 34, Supplement 1, p. 1549, 2013.

[36] Z. Ye, C. Smith, and I. J. Kullo, "Usefulness of red cell distribution width to predict mortality in patients with peripheral artery disease," The American Journal of Cardiology, vol. 107, no. 8, pp. 1241-1245, 2011.

[37] E. C. Seyhan, M. A. Özgül, N. Tutar, I. M. Ömür, A. Uysal, and S. Altın, "Red blood cell distribution and survival in patients with chronic obstructive pulmonary disease," COPD: Journal of Chronic Obstructive Pulmonary Disease, vol. 10, no. 4, pp. 416-424, 2013.

[38] G. Lippi, G. Targher, M. Montagnana, G. L. Salvagno, G. Zoppini, and G. C. Guidi, "Relationship between red blood cell distribution width and kidney function tests in a large cohort of unselected outpatients," Scandinavian Journal of Clinical and Laboratory Investigation, vol. 68, no. 8, pp. 745748, 2008.

[39] Y. H. Jo, K. Kim, J. H. Lee et al., "Red cell distribution width is a prognostic factor in severe sepsis and septic shock," The American Journal of Emergency Medicine, vol. 31, no. 3, pp. 545-548, 2013.

[40] M. Söderholm, Y. Borné, B. Hedblad, M. Persson, and G. Engström, "Red cell distribution width in relation to incidence of stroke and carotid atherosclerosis: a populationbased cohort study," PLoS One, vol. 10, no. 5, article e0124957, 2015.

[41] C. Ani and B. Ovbiagele, "Elevated red blood cell distribution width predicts mortality in persons with known stroke," Journal of the Neurological Sciences, vol. 277, no. 1-2, pp. 103-108, 2009.

[42] C. V. Hampole, A. K. Mehrotra, T. Thenappan, M. GombergMaitland, and S. J. Shah, "Usefulness of red cell distribution width as a prognostic marker in pulmonary hypertension," The American Journal of Cardiology, vol. 104, no. 6, pp. 868872, 2009.

[43] M. Tonelli, F. Sacks, M. Arnold et al., "Relation between red blood cell distribution width and cardiovascular event rate in people with coronary disease," Circulation, vol. 117, no. 2, pp. 163-168, 2008.

[44] S. Dabbah, H. Hammerman, W. Markiewicz, and D. Aronson, "Relation between red cell distribution width and clinical outcomes after acute myocardial infarction," The American Journal of Cardiology, vol. 105, no. 3, pp. 312-317, 2010.

[45] S. Nabais, N. Losa, A. Gaspar et al., "Association between red blood cell distribution width and outcomes at six months in patients with acute coronary syndromes," Revista Portuguesa de Cardiologia, vol. 28, no. 9, pp. 905-924, 2009.

[46] H. Uyarel, M. Ergelen, G. Cicek et al., "Red cell distribution width as a novel prognostic marker in patients undergoing primary angioplasty for acute myocardial infarction," Coronary Artery Disease, vol. 22, no. 3, pp. 138-144, 2011.

[47] T. Isik, M. Kurt, E. Ayhan, I. H. Tanboga, M. Ergelen, and H. Uyarel, "The impact of admission red cell distribution width on the development of poor myocardial perfusion after primary percutaneous intervention," Atherosclerosis, vol. 224, no. 1, pp. 143-149, 2012.

[48] G. Lippi, L. Filippozzi, M. Montagnana et al., "Clinical usefulness of measuring red blood cell distribution width on admission in patients with acute coronary syndromes," Clinical
Chemistry and Laboratory Medicine, vol. 47, no. 3, pp. 353357, 2009.

[49] F. Akin, N. Köse, B. Ayça et al., "Relation between red cell distribution width and severity of coronary artery disease in patients with acute myocardial infarction," Angiology, vol. 64, no. 8, pp. 592-596, 2013.

[50] E. Nikolsky, C. L. Grines, D. A. Cox et al., "Impact of baseline platelet count in patients undergoing primary percutaneous coronary intervention in acute myocardial infarction (from the CADILLAC trial)," The American Journal of Cardiology, vol. 99, no. 8, pp. 1055-1061, 2007.

[51] M. Lordkipanidzé, J. G. Diodati, J. Turgeon, E. Schampaert, D. A. Palisaitis, and C. Pharand, "Platelet count, not oxidative stress, may contribute to inadequate platelet inhibition by aspirin," International Journal of Cardiology, vol. 143, no. 1, pp. 43-50, 2010.

[52] C. N. Floyd and A. Ferro, "Mechanisms of aspirin resistance," Pharmacology \& Therapeutics, vol. 141, no. 1, pp. 69-78, 2014.

[53] K. Croce and P. Libby, "Intertwining of thrombosis and inflammation in atherosclerosis," Current Opinion in Hematology, vol. 14, pp. 55-61, 2007.

[54] E. Vagdatli, E. Gounari, E. Lazaridou, E. Katsibourlia, F. Tsikopoulou, and I. Labrianou, "Platelet distribution width: a simple, practical and specific marker of activation of coagulation," Hippokratia, vol. 14, no. 1, pp. 28-32, 2010.

[55] V. Asher, J. Lee, A. Innamaa, and A. Bali, "Preoperative platelet lymphocyte ratio as an independent prognostic marker in ovarian cancer," Clinical and Translational Oncology, vol. 13, no. 7, pp. 499-503, 2011.

[56] B. Azab, N. Shah, M. Akerman, and J. T. McGinn, "Value of platelet/lymphocyte ratio as a predictor of all-cause mortality after non-ST-elevation myocardial infarction," Journal of Thrombosis and Thrombolysis, vol. 34, no. 3, pp. 326-334, 2012.

[57] X. P. Sun, J. Li, W. W. Zhu et al., "Impact of platelet-tolymphocyte ratio on clinical outcomes in patients with STsegment elevation myocardial infarction," Angiology, vol. 68, no. 4, pp. 346-353, 2017.

[58] A. Yildiz, M. Yuksel, M. Oylumlu et al., "The utility of the platelet-lymphocyte ratio for predicting no reflow in patients with ST-segment elevation myocardial infarction," Clinical and Applied Thrombosis/Hemostasis, vol. 21, no. 3, pp. 223228, 2015.

[59] H. Vakili, M. Shirazi, M. Charkhkar, I. Khaheshi, M. Memaryan, and M. Naderian, "Correlation of plateletto-lymphocyte ratio and neutrophil-to-lymphocyte ratio with thrombolysis in myocardial infarction frame count in ST-segment elevation myocardial infarction," European Journal of Clinical Investigation, vol. 47, no. 4, pp. 322327, 2017.

[60] M. Kowara, K. Grodecki, Z. Huczek et al., "Platelet distribution width predicts left ventricular dysfunction in patients with acute coronary syndromes treated with percutaneous coronary intervention," Kardiologia Polska, vol. 75, no. 1, pp. 42-47, 2017.

[61] A. Bekler, M. T. Ozkan, E. Tenekecioglu et al., "Increased platelet distribution width is associated with severity of coronary artery disease in patients with acute coronary syndrome," Angiology, vol. 66, no. 7, pp. 638-643, 2015.

[62] M. Cetin, E. M. Bakirci, E. Baysal et al., "Increased platelet distribution width is associated with ST-segment elevation 
myocardial infarction and thrombolysis failure," Angiology, vol. 65, no. 8, pp. 737-743, 2014.

[63] T. Rechciński, A. Jasińska, J. Foryś et al., "Prognostic value of platelet indices after acute myocardial infarction treated with primary percutaneous coronary intervention," Cardiology Journal, vol. 20, no. 5, pp. 491-498, 2013.

[64] T. Celik, M. G. Kaya, M. Akpek et al., "Predictive value of admission platelet volume indices for in-hospital major adverse cardiovascular events in acute ST-segment elevation myocardial infarction," Angiology, vol. 66, no. 2, pp. 155$162,2015$.

[65] Z. Huczek, J. Kochman, K. J. Filipiak et al., "Mean platelet volume on admission predicts impaired reperfusion and long-term mortality in acute myocardial infarction treated with primary percutaneous coronary intervention," Journal of the American College of Cardiology, vol. 46, no. 2, pp. 284290, 2005.

[66] R. Estévez-Loureiro, J. Salgado-Fernández, R. Marzoa-Rivas et al., "Mean platelet volume predicts patency of the infarctrelated artery before mechanical reperfusion and short-term mortality in patients with ST-segment elevation myocardial infarction undergoing primary percutaneous coronary intervention," Thrombosis Research, vol. 124, no. 5, pp. 536-540, 2009.

[67] N. Taglieri, F. Saia, C. Rapezzi et al., "Prognostic significance of mean platelet volume on admission in an unselected cohort of patients with non ST-segment elevation acute coronary syndrome," Thrombosis and Haemostasis, vol. 106, no. 1, p. 132, 2011.

[68] A. A. López-Cuenca, A. Tello-Montoliu, V. Roldán, P. PérezBerbel, M. Valdés, and F. Marín, "Prognostic value of mean platelet volume in patients with non-ST-elevation acute coronary syndrome," Angiology, vol. 63, no. 4, pp. 241-244, 2012.

[69] S. G. Chu, R. C. Becker, P. B. Berger et al., "Mean platelet volume as a predictor of cardiovascular risk: a systematic review and meta-analysis," Journal of Thrombosis and Haemostasis, vol. 8, no. 1, pp. 148-156, 2010.

[70] Z. Huczek, K. J. Filipiak, J. Kochman et al., "Baseline platelet size is increased in patients with acute coronary syndromes developing early stent thrombosis and predicts future residual platelet reactivity. A case-control study," Thrombosis Research, vol. 125, no. 5, pp. 406-412, 2010.

[71] Y. G. Kim, J. W. Suh, C. H. Yoon et al., "Platelet volume indices are associated with high residual platelet reactivity after antiplatelet therapy in patients undergoing percutaneous coronary intervention," Journal of Atherosclerosis and Thrombosis, vol. 21, no. 5, pp. 445-453, 2014.

[72] F. Cesari, R. Marcucci, A. M. Gori et al., "Reticulated platelets predict cardiovascular death in acute coronary syndrome patients," Thrombosis and Haemostasis, vol. 109, no. 5, pp. 846-853, 2013.

[73] T. Isik, E. Ayhan, H. Uyarel et al., "Increased mean platelet volume associated with extent of slow coronary flow," Cardiology Journal, vol. 19, no. 4, pp. 355-362, 2012.

[74] M. R. Dehghani, Y. Rezaei, and L. Taghipour-Sani, "White blood cell count to mean platelet volume ratio as a novel non-invasive marker predicting long-term outcomes in patients with non-ST elevation acute coronary syndrome," Cardiology Journal, vol. 22, no. 4, pp. 437-445, 2015.

[75] G. Çiçek, S. K. Açıkgöz, Ç. Yayla, H. Kundi, and M. İleri, "White blood cell count to mean platelet volume ratio: a novel and promising prognostic marker for ST-segment elevation myocardial infarction," Cardiology Journal, vol. 23, pp. 225235, 2016.

[76] S. Balta, T. Celik, D. P. Mikhailidis et al., "The relation between atherosclerosis and the neutrophil-lymphocyte ratio," Clinical and Applied Thrombosis/Hemostasis, vol. 22, no. 5, pp. 405411, 2016.

[77] L. Pizzuli, A. Yang, J. F. Martin, and B. Luderitz, "Changes in platelet size and count in unstable angina compared to stable angina or non-cardiac chest pain," European Heart Journal, vol. 19, no. 1, pp. 80-84, 1998.

[78] G. De Luca, L. Venegoni, S. Iorio et al., "Platelet distribution width and the extent of coronary artery disease: results from a large prospective study," Platelets, vol. 21 , no. 7, pp. 508$514,2010$.

[79] N. Sivri, G. Tekin, K. Yalta, Y. Aksoy, K. Senen, and E. Yetkin, "Statins decrease mean platelet volume irrespective of cholesterol lowering effect," Kardiologia Polska, vol. 71, no. 10, pp. 1042-1047, 2013.

[80] A. T. Timóteo, A. L. Papoila, A. Lousinha et al., "Predictive impact on medium-term mortality of hematological parameters in acute coronary syndromes: added value on top of GRACE risk score," European Heart Journal: Acute Cardiovascular Care, vol. 4, no. 2, pp. 172-179, 2015.

[81] H. Acet, F. Ertaş, M. A. Akıl et al., "Relationship between hematologic indices and global registry of acute coronary events risk score in patients with ST-segment elevation myocardial infarction," Clinical and Applied Thrombosis/Hemostasis, vol. 22, no. 1, pp. 60-68, 2016.

[82] A. Kurtul, S. N. Murat, M. Yarlioglues et al., "Association of platelet-to-lymphocyte ratio with severity and complexity of coronary artery disease in patients with acute coronary syndromes," The American Journal of Cardiology, vol. 114, no. 7, pp. 972-978, 2014.

[83] Z. F. Wan, D. Zhou, J. H. Xue et al., "Combination of mean platelet volume and the GRACE risk score better predicts future cardiovascular events in patients with acute coronary syndrome," Platelets, vol. 25, no. 6, pp. 447-451, 2014.

[84] X. Niu, C. Yang, Y. Zhang, H. Zhang, and Y. Yao, "Mean platelet volume on admission improves risk prediction in patients with acute coronary syndromes," Angiology, vol. 66, no. 5, pp. 456-463, 2015. 


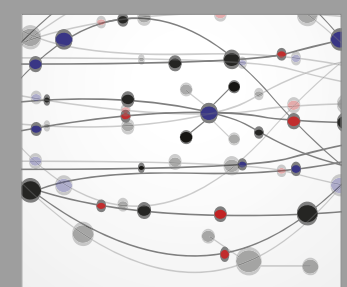

The Scientific World Journal
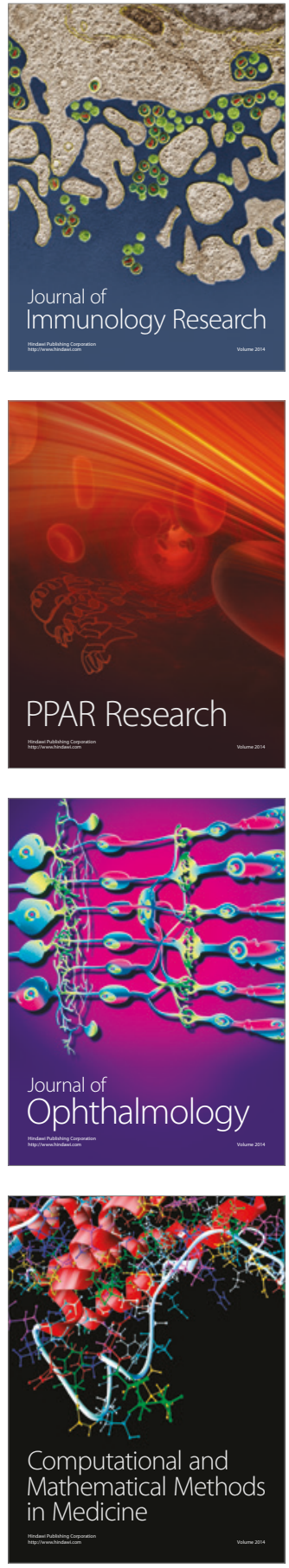

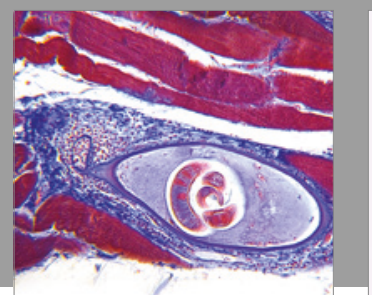

Gastroenterology Research and Practice
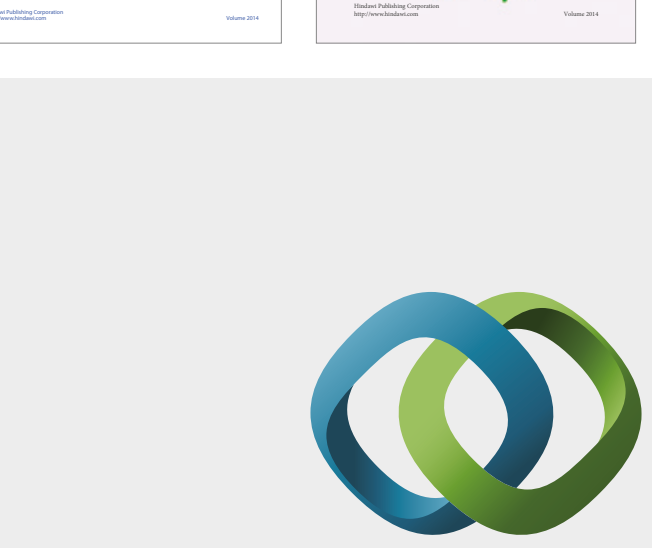

\section{Hindawi}

Submit your manuscripts at

https://www.hindawi.com
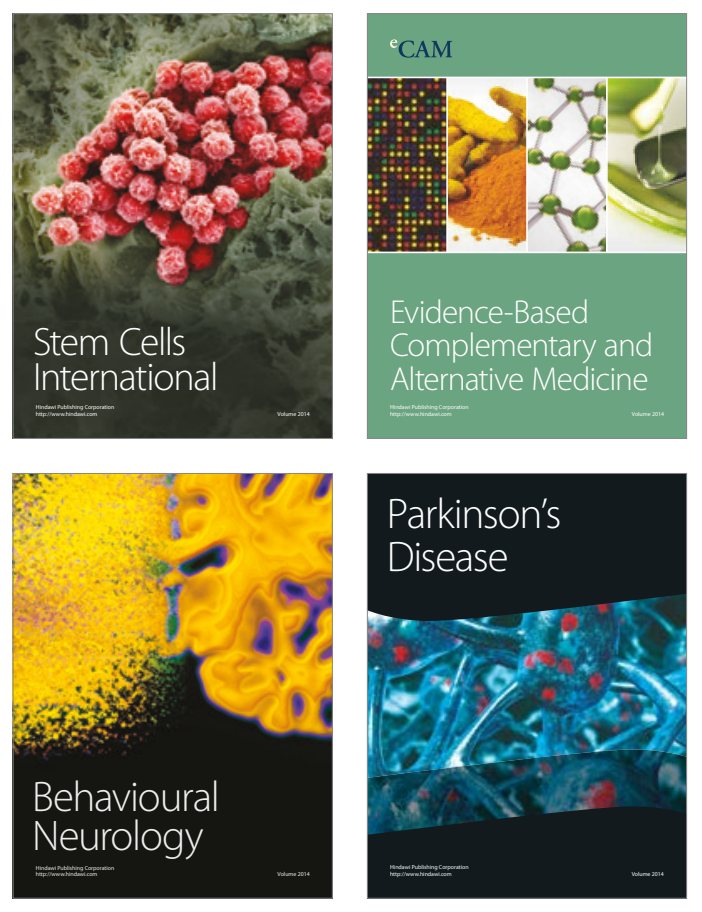
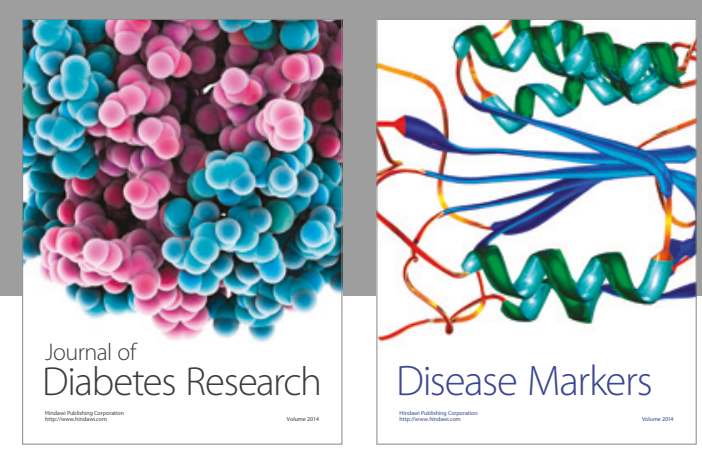

Disease Markers
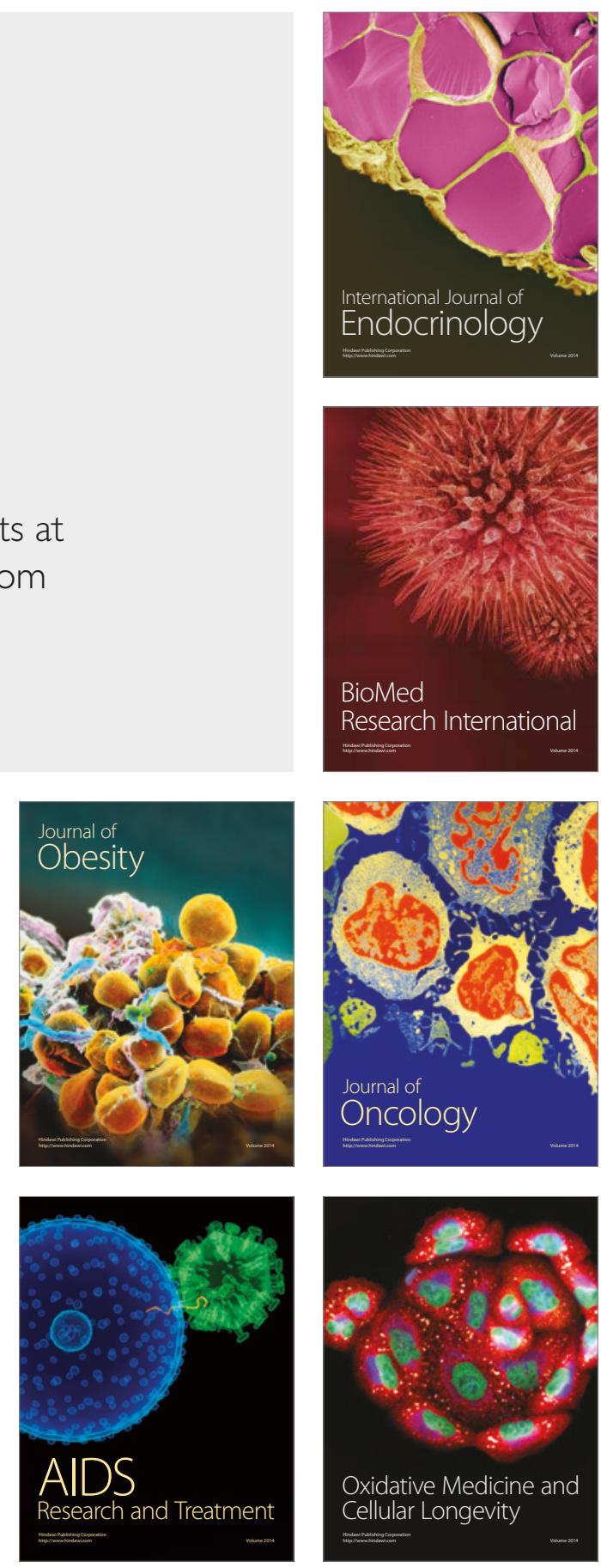